\title{
De lavradora a professora primária na roça: narrativas, docência e profissionalização*
}

\author{
JANE ADRIANA VASCONCELOS PACHECO RIOS \\ Universidade do Estado da Bahia, Salvador, BA, Brasil
}

\section{RESUMO}

O texto apresenta as narrativas de formação de professoras da roça, buscando compreender os processos de profissionalização da docência no ensino fundamental. $\mathrm{O}$ estudo analisou, com base em percursos formativos, as experiências de docentes no processo de constituição identitária de ex-lavradoras que assumiram a docência na busca pela construção da profissão docente na roça. Para isso, baseou-se na abordagem (auto)biográfica, utilizando-se das narrativas de vida-formação-profissão de quatro professoras que lecionavam em escolas rurais do interior da Bahia. As narrativas descrevem os múltiplos vínculos estabelecidos na escola, no tecido das relações sociais vividas pelas docentes, na própria comunidade da qual fazem parte, apresentando os lugares discursivos ocupados por elas na produção da profissão docente na roça.

PALAVRAS-CHAVE

profissão docente; roça; ensino.

* Este trabalho faz parte da pesquisa de pós-doutoramento $A$ profissão docente na roça: narrativas de formação no Piemonte da Chapada Diamantina/Babia, realizada na Universidade de São Paulo (USP) em parceria com o Centro de Estudos Rurais e Urbanos no período de 2012 a 2013. 


\title{
FROM WOMAN FARMER TO SECONDARY TEACHER IN THE COUNTRY: STORIES, TEACHING AND PROFESSIONALIZATION
}

\begin{abstract}
The following text introduces stories of the country teacher's formation, aiming to comprehend the professionalization process of secondary school teaching. This research has analyzed, from the developmental pathway, the experiences in identifying the constitution process of the ex-ploughman that became teacher. Thereunto, life-formation-profession stories, have been collected, of four teachers who work in country schools in Bahia, Brazil. These stories describe the multiple connections within the school, established between these teachers and the community of which they are part.
\end{abstract}

KEYWORDS

teacher occupation; country; secondary.

DE CAMPESINA A PROFESORA PRIMARIA RURAL: NARRATIVAS, DOCENCIA Y PROFESIONALIZACIÓN

\section{RESUMEN}

El texto presenta las narrativas de formación de profesoras rurales y busca comprender los procesos de profesionalización de la docencia en la educación primaria. El estudio analizó, tomando por base recorridos formativos, las experiencias de docentes en el proceso de constitución de identidad de ex campesinas que se hicieron cargo de la docencia en busca de la construcción de la profesión docente en el campo. Con tal objeto se ha basado en el abordaje (auto)biográfico, utilizando las narrativas de vida-formación-profesión de cuatro profesoras que enseñaban en escuelas rurales del interior de Bahía, Brasil. Las narrativas describen los múltiples vínculos que se establecen en la escuela, en el tejido de las relaciones sociales vividas por las docentes en su propia comunidad, de la que forman parte, presentando los lugares discursivos que ocupan esas mujeres en la producción de la profesión docente en el campo.

PALABRAS CLAVE

profesión docente; campo; enseñanza. 
$\mathrm{Na}$ contemporaneidade, a constituição da docência vive um movimento híbrido. Ser professor representa um grande desafio, uma vez que estamos diante de uma profissão que se configura em um espaço múltiplo de produção do sujeito. Hoje, pensar a profissão docente significa retomar as diferentes trajetórias que educadores foram construindo ao longo da história dessa profissão, em diferentes tempos e espaços. Diante desse cenário, apresentamos neste trabalho as narrativas de vida-formação-profissão de professoras da roça, ${ }^{1}$ buscando compreender os processos de profissionalização docente vividos em escolas situadas em áreas rurais no interior da Bahia. ${ }^{2}$

No que se refere à profissão docente, esta pesquisa dialogou com estudos realizados por Nóvoa $(1991,1999)$ e buscou compreender, com base em seu modelo interpretativo, como a docência, ao longo do tempo e das histórias de vida, vai tornando-se uma profissão, utilizando-se da profissionalização como um elemento fundante do desenvolvimento da categoria. A profissão docente é tomada aqui como uma atividade que se faz cotidianamente, no bojo das experiências que cada educador vivencia na construção de sua própria existência. Assim, a profissão movimenta-se valendo-se de experiências outras que não estão apenas no espaço da escola, mas na trajetória de seus docentes. É nessa perspectiva que esta pesquisa se insere, ao tratarmos da profissão docente na roça, cuja profissionalização surge do enraizamento e da implicação de professoras na comunidade rural da qual fazem parte.

Analisar a docência na roça implica refletir sobre os modos de vida traduzidos na maneira como as professoras construíram a profissionalização docente ao longo de suas carreiras. Para isso, este estudo buscou a trajetória de quatro professoras que nasceram, cresceram e experimentaram as práticas das lidas na roça, formando-se a partir das experiências com a terra. $\mathrm{O}$ trabalho na roça como lavradoras ocupou simbolicamente um espaço de formação para as docentes, representando o aprendizado do repertório da vida no campo.

Com o objetivo de apreender os sentidos acerca da produção da vida-profissão dessas mulheres, o estudo fundamentou-se na pesquisa (auto)biográfica por entender que a narrativa traz a experiência do vivido, possibilitando desvelar os diferentes percursos que as docentes fizeram na busca pela profissionalização. Justamente por considerar a singularidade presente em cada narrativa e por saber que nelas se imprime a marca do narrador (Benjamin, 1994), optamos por tomar a narrativa como um núcleo do processo de investigação. Essa opção metodológica delineou-se também como uma prática formativa, em que as experiências pedagógicas do coletivo foram tomadas como dispositivos de investigação-ação-formação.

1 A roça é entendida aqui como uma ruralidade específica envolta na semiótica da terra (Rios, 2011).

2 O estado da Bahia, a partir do decreto n. 12.354/2010, instituiu o Programa Territórios de Identidade, reconhecendo em seu planejamento territorial vinte e seis territórios de identidade, considerando especificidades sociais, culturais, econômicas e geográficas. Esta pesquisa foi desenvolvida no território de identidade do Piemonte da Diamantina, constituído por nove municípios: Caém, Capim Grosso, Jacobina, Mirangaba, Ourolândia, Saúde, Serrolândia, Umburanas e Várzea Nova. 
A pesquisa foi dividida em duas etapas: a primeira, denominada espaço vivencial, procurou identificar, caracterizar e analisar as práticas discursivas/pedagógicas que constituem o fazer, o dizer e o ser professor nas escolas da roça, por meio do mapeamento das escolas e seus docentes. A segunda etapa, nomeada histórias de vida-formação-profissão, consistiu na biografização das narrativas dos professores que se encontravam em atividade nas escolas da roça, tendo por objetivo analisar a constituição da profissão docente. Para a seleção das narradoras deste trabalho, foi observado o perfil biográfico, considerando a caminhada das professoras em suas experiências como educadoras leigas e a relação com o trabalho na terra em suas comunidades, marcando a trajetória da lavoura à docência como um percurso formativo e constitutivo.

Apresentamos, inicialmente, um sobrevoo histórico sobre a docência no meio rural e, em seguida, retomamos as trajetórias das professoras, em seu processo de constituição da profissão docente na roça. Esperamos que o texto possa contribuir para futuras investigações sobre a docência na educação rural e no campo, impulsionando as intervenções formativas desses sujeitos, com apoio e ponto de partida no conhecimento local, fruto de práticas pedagógicas que articulam os saberes pessoais e profissionais da docência na roça.

\section{DOCÊNCIA NO MEIO RURAL: SOBREVOO HISTÓRICO}

Há uma lacuna na historiografia da educação brasileira: a educação rural e, consequentemente, a formação de seus professores não têm sido estudada com a constância necessária. Essa temática vem sendo marcada por silenciamentos produzidos e incorporados às práticas e políticas educacionais que continuam imprimindo marcas de negação ao direito à educação para a população rural.

Em muitos estados do Nordeste, as ações de fixação do homem e/ou da mulher ao campo surgem em decorrência do fluxo migratório ocasionado pelas grandes estiagens que marcaram, sobretudo, a década de 1930. Nesse cenário, surgem as primeiras iniciativas de inserção da educação no meio rural por meio do ruralismo pedagógico (corrente teórica que pretendia gerar uma escola integrada às condições locais), cujo objetivo era promover a fixação do homem e da mulher ao campo.

No ruralismo pedagógico, o docente era entendido como uma pessoa importante para a formação ideológica dos trabalhadores, tendo a incumbência de evitar que eles migrassem do meio rural para as periferias das cidades, ensinando-os a lidar com o solo, com a pecuária e o cultivo de outros tipos de culturas. O professor deveria ser um trabalhador diferenciado nas comunidades rurais por ser um profissional preparado pelos livros para lidar com a produtividade do campo. Diante dessa tarefa, começa a surgir a preocupação com a formação específica do docente rural, o que impulsionou a criação da Escola Normal Rural, vinculando a formação de professores, inicialmente, à ideia de civilizar e levar o progresso ao meio rural.

Nesse contexto, surge, em 1934, a primeira Escola Normal Rural, instalada em Juazeiro do Norte, estado do Ceará, com o objetivo de formar professores para a zona rural do Nordeste. Assim, há alguns investimentos na docência, como a criação de prédios escolares em comunidades rurais. Entretanto, muitos locais, entre 
eles o interior da Bahia, não contavam com docentes formados em escola normal, prevalecendo nas escolas rurais, por várias décadas do século $\mathrm{XX}$, a forte presença e a atuação de professores leigos.

Na Bahia, em 1925, por meio da lei n. 1.846, no governo de Francisco Góes Calmon, auxiliado pelo então diretor de Instrução Pública, na época o educador Anísio Teixeira, foi realizada uma reforma no ensino estadual responsável pela criação de escolas de curso normal no interior do estado. Nesse momento, a ênfase estava no ensino primário, visto que grande parte da população baiana em idade escolar encontrava-se fora da escola e a educação primária rural estava nas mãos de docentes leigos. As escolas normais rurais buscavam atender à necessidade de profissionalização de docentes no interior da Bahia.

No território do Piemonte da Diamantina, espaço de realização desta pesquisa, a Escola Normal surgiu em 1939, no município de Jacobina, com a criação do Instituto de Educação Senhor do Bonfim, transferido do município de Senhor do Bonfim $^{3}$ em convênio com a Prefeitura Municipal de Jacobina. A escola tinha como objetivo contribuir na formação de docentes para a atuação nas escolas isoladas da microrregião, atendendo a um público mais abastado da cidade, que muitas vezes, porém, após a conclusão do curso, não atuava nas escolas rurais.

Diante desse quadro, na década de 1950, algumas iniciativas educacionais voltadas para as comunidades rurais são colocadas em prática, entre elas a criação da Campanha Nacional de Educação Rural (CNER), atuando em quase todo o território nacional na formação de líderes em missões rurais, semanas educativas e campanhas educacionais. Em relação à formação dos professores rurais, o CNER ofereceu, em 1952, cursos regionais de treinamento de professores rurais, para o aperfeiçoamento do trabalho docente, destinados a docentes leigos, visando não apenas à formação pedagógica mas à sua transformação em verdadeiras lideranças nas comunidades.

Os anos de 1960 chegam com o impulso dos movimentos sociais, entre eles os movimentos de educação popular, que tiveram papel fundamental na construção de novas ações pedagógicas e sociais, inaugurando uma nova perspectiva de educação para as comunidades rurais com base nos fundamentos da teologia da libertação e nas ideias de Paulo Freire. Entre esses movimentos, destacaram-se o Centro Popular de Cultura (CPC), o Movimento Educacional de Base (MEB) e o Movimento de Cultura Popular (MCP). Nesse período, ressalta-se também a atuação dos movimentos de ação católica e dos movimentos sociais do campo (ligas camponesas, sindicatos rurais) que, com alguns educadores, foram se articulando em busca do direito a terra e a educação nas áreas rurais.

Com o problema do analfabetismo - que naquela época já era enorme - o governo militar buscou soluções por meio do Plano Nacional de Desenvolvimento (PND) e, depois, com o Plano Setorial de Educação, Cultura e Desporto (PSEDC), dando suporte aos programas oferecidos pelo Ministério da Educação (MEC), tais como o Programa Nacional de Ações Socioeducativas e Culturais para o meio

3 Município localizado no território do Piemonte Norte do Itapicuru, no interior da Bahia. 
rural (PRONASEC), o Programa de Expansão e Melhoria da Educação no Meio Rural do Nordeste (EDURURAL/NE) e o Movimento Brasileiro de Alfabetização (MOBRAL).

Com a Constituição de 1988, abre-se um novo momento na educação brasileira, agora marcado pela chegada da Lei de Diretrizes e Bases da Educação Nacional (LDBEN n. 9.394/1996), que por meio de seu artigo 28 prevê a oferta de educação básica para a população rural, garantindo a adaptação às peculiaridades de cada região com conteúdos curriculares específicos e o respeito ao calendário agrícola. Há um avanço significativo com essa lei, porém o papel dos municípios seria essencial para a sua vigência, considerando que, até o momento em que adentramos o século XXI, ainda persistem os velhos problemas, especialmente aqueles relacionados à situação do professor. Não há iniciativas de formação específica, há problemas de acesso às escolas e clientelismo político no processo de contratação, entre outros. No período de 2002 a 2005, apesar de a proporção de docentes leigos atuando no ensino primário brasileiro ter sofrido certa redução, de 8,3\% para $3,4 \%$, ainda há um número significativo de professores sem formação específica em atividade (INEP, 2007).

Nas duas últimas décadas do século XX, entretanto, tem início uma nova concepção de educação para as comunidades do meio rural, sendo resultado especialmente de reivindicações dos segmentos sociais organizados. É nesse espaço de lutas e embates que começa a delinear-se no país uma política pública de educação do campo, cujo marco inicial está no final dos anos de 1990, com a realização dos seguintes eventos: I Encontro Nacional de Educadoras e Educadores da Reforma Agrária (ENERA, 1997) e I Conferência Nacional: por uma Educação Básica do Campo (1998). Foram criados, também em 1998, a Articulação Nacional por uma Educação do Campo, entidade responsável pela promoção e gestão das ações pela construção de uma política nacional de educação do campo, e o Programa Nacional de Educação na Reforma Agrária (PRONERA), ambos favorecendo a formação de educadores e educadoras específicos para o campo.

A resolução CNE/CEB n. 1/2002 destaca que o exercício da docência em escolas do campo respeitará o que propõem os artigos 12,13, 61 e 62 da LDBEN de 1996 e as resoluções n. 3/1997 e n. 2/1999, da Câmara da Educação Básica. Além disso, os pareceres n. 9/2002 e n. 28/2002, ${ }^{4}$ do Conselho Nacional de Educação, estabelecem a formação em nível superior para o exercício da docência na educação básica. Na Bahia, embora o Plano Estadual de Educação (PPE) defina e estimule a política de valorização e de formação dos profissionais da educação, ainda existe um número muito elevado de educadores atuando no campo sem a devida qualificação e as condições mínimas necessárias a um trabalho de qualidade, como podemos observar no Quadro 1.

4 A informação encontra-se nas Diretrizes Operacionais para a Educação Básica nas Escolas do Campo (Brasil, 2002), que afirmam o atendimento às resoluções n. 3/1997 e n. 2/1999 e aos pareceres n. 9/2002 e n. 28/2002. 
Quadro 1 - Distribuição dos docentes que lecionam em escola rurais na Bahia, por grau de formação

\begin{tabular}{|c|c|c|c|c|c|}
\hline $\begin{array}{c}\text { Fundamental } \\
\text { incompleto }\end{array}$ & $\begin{array}{c}\text { Fundamental } \\
\text { completo }\end{array}$ & $\begin{array}{c}\text { Ensino médio } \\
\text { normal/ } \\
\text { magistério }\end{array}$ & $\begin{array}{c}\text { Ensino } \\
\text { médio normal/ } \\
\text { magistério/ } \\
\text { indígena }\end{array}$ & $\begin{array}{c}\text { Ensino } \\
\text { médio }\end{array}$ & $\begin{array}{c}\text { Superior } \\
\text { completo/ } \\
\text { licenciatura }\end{array}$ \\
\hline 208 & 1.044 & 78.351 & 316 & 18.381 & 38.828 \\
\hline
\end{tabular}

Fonte: INEP (2010).

Em relação a esse aspecto, é necessário ressaltar a criação da Política Nacional de Formação de Profissionais do Magistério, por meio do decreto n. 6.755/2009 (Brasil, 2009a), que teve como finalidade atender à demanda por formação inicial e continuada de docentes das redes públicas de educação básica. Para isso, foi criado o Plano Nacional de Formação de Professores da Educação Básica (PARFOR) (portaria n. 9/2009) (Brasil, 2009b), em regime de colaboração com o MEC, por meio da Coordenação de Aperfeiçoamento de Pessoal de Nível Superior (CAPES), secretarias de educação dos estados, Distrito Federal e municípios e as instituições de ensino superior, com o objetivo de ofertar cursos de licenciatura para docentes em exercício.

Diante desse panorama histórico, buscamos nas trajetórias de vida-formação-profissão de quatro mulheres, ex-lavradoras, compreender como o cenário apresentado foi vivenciado e ressignificado em suas práticas cotidianas, partindo de três aspectos que aparecem de forma fecunda nas narrativas, a saber: 1) a entrada na profissão; 2) as licenças para ensinar no primário; e 3) a profissionalização no exercício da docência na roça.

\section{A ENTRADA NA PROFISSÃO}

Ser professor na roça exige um movimento de deslocamento e pertencimento de cada sujeito envolvido. Constituir os processos identitários da profissão significa pensar o exercício do magistério como o modo de vida de um grupo profissional, observando espaços e temporalidades distintos que constituem a docência.

Conforme dados históricos apresentados no tópico anterior, a profissão docente chega no interior da Bahia de forma bastante precária. Os saberes necessários ao exercício da docência estavam vinculados apenas ao saber ler, escrever e contar, habilidades proporcionadas até a antiga quarta série primária. Esse modelo de racionalidade fez com que as professoras, sujeitos desta pesquisa, iniciassem a carreira docente como professoras leigas. Historicamente, no Brasil, a expressão professor leigo guarda relação com a laicidade do ensino em contraponto ao ensino religioso e/ou à liberdade do exercício do magistério, consagrado no país pela legislação normativa da educação escolar. Geralmente, tais professores eram mulheres convocadas a construir a docência no meio rural, nas chamadas escolas isoladas, assumindo classes multisseriadas (Picanço, 1986). 
Dado o alto índice de analfabetismo em áreas rurais, a demanda pelo trabalho docente foi entrando em evidência no território do Piemonte da Diamantina, no interior da Bahia. Porém não havia cursos de formação docente suficientes para atender à demanda dos municípios, principalmente a necessidade das áreas rurais. Para a legislação educacional vigente na época, a LDBEN n. 5.692/1971, a admissão de professores precariamente habilitados para atender às necessidades do ensino era possível, tendo em vista a falta de docentes em determinadas regiões do país, como podemos observar no parágrafo único do artigo 77 :

Onde e quando persistir a falta real de professores, após a aplicação dos critérios estabelecidos neste artigo, poderão ainda lecionar:

a) no ensino de $1^{\circ}$ grau, até a $6^{a}$ série, candidatos que hajam concluindo a $8^{\mathrm{a}}$ série e venham a ser preparados em cursos intensivos;

b) no ensino de $1^{\mathrm{o}}$ grau, até a $5^{\mathrm{a}}$ série, candidatos habilitados em exames de capacitação regulada, nos vários sistemas, pelos respectivos Conselhos de Educação. (Brasil, 1971)

Baseados nesses termos legais, os gestores municipais contratavam de forma precária as jovens professoras, que mal terminavam o primário e já assumiam a docência na roça. É nesse contexto que se inscrevem as quatro professoras aqui pesquisadas: Marta, Eva, Sandra e Lina. ${ }^{5}$ Elas iniciaram a profissão na adolescência, entre as décadas de 1970 e 1990, em espaços cedidos na própria casa ou pela comunidade, como professoras leigas. Essas mulheres eram filhas de pequenos agricultores familiares e viviam de seus próprios trabalhos com a terra.

$\mathrm{O}$ ingresso na profissão de docente na roça foi marcado pela necessidade de atender a demandas locais, caracterizando uma iniciação à docência precoce, com a precarização das diversas condições de exercício do magistério, como nos relata Eva:

Quando eu cheguei aqui, essa região não tinha professor e tinha muita gente analfabeta: adolescente, criança, adulto. Muita gente! Como eu já tinha concluído até a quarta série, o pessoal começou a pedir: "Você podia ensinar aos nossos filhos?" [...] Com isso, eu comecei a ensinar com catorze anos de idade. [...] quando eu comecei, eu ensinava na casa de um tio meu, nesta mesma localidade, distante daqui de casa uns três quilômetros. Com oito dias de aula, meu tio começou a ficar chateado com a juventude e aí eu mudei pra casa do meu pai.

$\mathrm{O}$ quadro educacional apresentado pela docente traz as marcas do forte analfabetismo existente na região, elemento que impulsionou o crescimento do número de docentes leigos no território estudado. Nesse contexto, as professoras leigas

5 Conforme Termo de Consentimento Livre e Esclarecido (TCLE), apresentado ao Comitê de Ética da Universidade do Estado da Bahia (UNEB), ao qual esta pesquisa está submetida, a identidade das professoras foi preservada mediante utilização de nomes fictícios. 
substituíram os professores itinerantes, ${ }^{6}$ que ficavam em fazendas trabalhando com a escolarização básica (ler, escrever e contar) dos estudantes das comunidades rurais. $\mathrm{O}$ uso de salões ou casas alugadas para o funcionamento das aulas não era comum àquela região no período em que as docentes iniciaram suas carreiras. Por isso, as turmas funcionavam numa espécie de escola doméstica, situada em residências, galpões, depósitos, salões improvisados pela comunidade, realidade muito próxima daquela que as docentes viveram quando eram estudantes. No caso específico de Eva, a pobreza que circundava a sua família era tão grande que não tinha como contar, inicialmente, com um dos cômodos de sua casa para as aulas, tendo de se submeter a longas caminhadas e a intromissões familiares para começar a ensinar.

O processo inicial de formação das professoras foi marcado pelas experiências como estudantes/trabalhadoras que vivenciaram a escola na relação partilhada com os saberes e fazeres produzidos na roça. Essa experiência do vivido, presente nas narrativas, trazia o lugar da profissão valendo-se das memórias da escola materializadas no fazer da antiga professora rural. Marta relata as dificuldades que teve para estudar e a relação disso com o fazer docente na roça:

Para eu estudar foi muito difícil, porque a gente morava numa região muito isolada, que não tinha transporte para levar a gente até a escola. Então os fazendeiros se reuniram e pagaram uma professora leiga para alfabetizar os alunos daquela região. [...] Ela juntava todo mundo, não tinha essa questão de série. Uns já sabiam ler, outros não. Ficava todo mundo na mesma turma e passava o ano todo juntos. [...] Nós estudávamos à tarde, e, pela manhã, meus irmãos ajudavam meu pai na roça e eu ajudava minha mãe com o sisal.

A fala de Marta traz à tona o tratamento residual que o ensino em áreas rurais sempre teve ao longo da história da educação brasileira. $\mathrm{O}$ acesso à educação dos moradores da roça sempre foi uma demanda, tendo em vista a falta de políticas públicas voltadas para esse objetivo. Marta anuncia em sua fala um modelo de construção de professor oriundo da ausência dessas políticas no meio rural. Bastava-lhe a experiência de estudante vivida no primário para ter a possibilidade de ingresso na profissão docente na roça. O modelo copiado do antigo professor leigo era utilizado e repassado a todas aquelas mulheres que assumiam a profissão.

A entrada das professoras na docência também foi marcada pela atuação em classes multisseriadas ou unidocentes. Esse modelo remonta às origens dos professores itinerantes, que, após a expulsão dos jesuítas, passaram a ensinar as primeiras letras de fazenda em fazenda. Conforme Atta (2003), as classes multisseriadas foram criadas oficialmente pela Lei Geral do Ensino, em 1827, que determinava a necessidade de existência de escolas de primeiras letras em todos os lugares populosos. $\mathrm{O}$ ensino de pessoas de diferentes idades e níveis foi assumido

6 Termo utilizado por Vicentini e Lugli (2009) para caracterizar o professor contratado temporariamente pelos pequenos agricultores para ensinar tudo o que sabia em uma fazenda e viajar para outra. No caso específico desta pesquisa, o ensino era em uma comunidade. 
e incentivado no século XIX, sobretudo com a utilização do método lancasteriano, por meio do processo mútuo.

Mais de um século depois, as professoras da roça, sujeitos desta pesquisa, iniciaram sua profissão, lecionando para alunos com diferentes níveis de aprendizagem, agrupados por séries, em uma mesma classe. Mais uma vez, as classes multisseriadas assumiram a responsabilidade pela iniciação escolar na roça. Marta revela as dificuldades vividas no início da carreira pela experiência com as classes multisseriadas:

[...] Eu comecei ensinando classes multisseriadas, na verdade eu sempre trabalhei com séries multisseriadas, desde o início, e era do pré à quarta série. Foi muito complicado começar a ensinar sem ser formada e com multisseriado. Era muito difícil! Eu já tinha uma certa vivência porque eu sempre estudei em classe multisseriada, então eu agrupava as crianças por nível de desenvolvimento, porque eu já estudava nesse processo. Minha professora já fazia assim, e eu já tinha de certa forma a experiência de aluna com essa metodologia. A gente sempre trabalhou dessa forma. Era difícil!

A docente imprimiu ao seu fazer as identidades coletivas de um grupo com base nas experiências de vida-formação-profissão que constituíram o trabalho docente em classes multisseriadas. Por falta de formação específica para trabalhar com a multisseriação, Marta e sua antiga professora construíram os próprios métodos de trabalho para enfrentar a diversidade de suas turmas. Exceto os modelos vivenciados na prática como estudantes, elas não tiveram nenhuma orientação específica para o trabalho.

A situação narrada por Marta é tomada por Josso (2004) como recordações-referências, qualificadas como experiências formadoras, pelo fato daquilo que foi aprendido servir de referência a diversas situações orientadoras de uma vida, nesse caso específico, base para a atuação em sala de aula. A autora afirma que a narrativa de formação de cada indivíduo conduz a uma reflexão antropológica, ontológica e axiológica. Nesse sentido, a experiência produz as características do contexto cultural e socio-histórico em que as docentes estavam envolvidas, além de retomar as questões identitárias, tornando evidentes os eixos que estruturam e orientam a existência de cada uma delas na construção da profissão. As professoras eram parte da comunidade, participaram da construção social da escola no meio rural.

É nesse sentido de construção de um modelo de docência que as professoras passaram a vivenciar as classes multisseriadas, fazendo exatamente o que seus antigos formadores faziam. Nesse caso, a situação ficou ainda mais difícil para as quatro professoras leigas deste estudo, cujas narrativas mostram a marca da insegurança nos percursos formativos que serviram para a construção da profissão. A base principal que tinham era a seriação e, assim, dividiam a turma e o quadro pelo nivel de desenvolvimento dos alunos, metodologia ainda muito comum nas escolas dessa região para lidar com a multisseriação. A falta de formação para o trabalho com as classes multisseriadas foi algo constante na vida das professoras da roça. 
$O$ único programa direcionado às classes multisseriadas mencionado nas narrativas das docentes foi o Programa Escola Ativa, política pública implementada pelo Estado em 1987, destinado a melhorar a qualidade do desempenho escolar em classes multisseriadas das escolas do campo. O programa fez parte de uma série de iniciativas do governo federal sobre a educação do campo, tomadas no sentido de formar o maior número de docentes, produzindo material didático e oferecendo alternativas de formação em serviço. Segundo Sandra, o programa chegou ao seu município em 2011, e as mudanças propostas foram lentas, uma vez que:

O Escola Ativa é um programa novo para a gente, é por isso que não fazemos nada mais concreto para o aluno da roça. [...] O programa chegou o ano passado e mandou muito material: bússola, esqueleto. Tem vez que a gente usava, tem vez que não. Agora, para as classes multisseriadas, não mudou nada não. No multisseriado, é difícil você querer fazer uma coisa mais aumentada, mas o outro, que é atrasado, não sabe, então você acaba fazendo por fazer [...].

A docente apresenta as fragilidades vivenciadas na formação específica para o trabalho com as classes multisseriadas, revelando que o investimento apenas em material didático não foi suficiente para o fazer docente nessas turmas. No processo de formação, o professor tem de possuir certos saberes, porém precisa compreendê-los para poder intervir. Nesse sentido, o trabalho com as classes multisseriadas requer uma política de formação mais coerente com a realidade em que essa organização escolar foi alicerçada ao longo dos anos. Coerente, sobretudo, com a realidade em que os sujeitos estão inseridos e com o papel que a multisseriação ocupou na história da educação no meio rural.

Justamente na busca por novos itinerários de formação e profissão que as docentes apresentam outros caminhos para a profissionalização na roça, inserindo, nesse movimento, a passagem de professora leiga para professora habilitada no magistério.

\section{AS LICENÇAS PARA ENSINAR NO PRIMÁRIO}

No início da carreira, as professoras da roça, sujeitos desta pesquisa, validaram a atuação na profissão com base nos mecanismos de reconhecimento tecidos nas relações sociais da quais participaram, direta ou indiretamente, entre elas as interferências de políticos e a mobilização da comunidade local. Nas comunidades pouco escolarizadas, a produção de uma licença não oficial para lecionar tendo estudado apenas até a quarta série era proporcionada pelos favores políticos, relações familiares, de amizade e compadrio, como podemos observar na narrativa de Lina:

Com dezenove pra vinte anos, chegou um vereador na comunidade e me ofereceu um trabalho de professora. Como eu necessitava de um trabalho pra ajudar a família e lá estava sem professor, acabei aceitando, mesmo tendo apenas a quarta série. Naquele tempo, os professores entravam pra sala de aula pra tomar conta de um grupo escolar com a quarta série. Minha professora mesmo era 
assim! [...] Então, eu fui pra sala da aula como professora e não lembro o ano mesmo. Eu comecei com um fichamento, a gente preenchia uma ficha e você começava a trabalhar na profissão como professora.

Segundo Vicentini e Lugli (2009), a partir da década de 1930 é que se iniciaram, no Brasil, os processos de seleção de docentes, buscando eliminar o peso das relações pessoais e a intromissão das forças políticas locais nos processos de nomeação e seleção para o magistério público. Para as autoras, a aprovação em concurso era determinante para a constituição da identidade profissional dos professores, possibilitando estabilidade e permanência na função exercida.

Entrar na profissão, vincular-se a uma instituição, acontecia de diversas formas. Após ter preenchido uma ficha na prefeitura, Lina foi inserida no quadro de professores daquele município. Já Marta, Eva e Sandra foram contratadas. E Eva teve seu registro de professora, inicialmente, concedido no nome de sua mãe: "[...] eu comecei a ensinar com catorze anos de idade. Como eu era muito jovem, não aceitaram colocar meu nome como professora e colocaram o nome de minha mãe. Eu era a professora, mas era tudo no nome de minha mãe”.

Com o passar do tempo, as docentes foram convocadas a realizar o concurso para professores leigos, fazendo provas específicas que garantissem a manutenção de suas atividades nas escolas. Esse concurso foi instituído no Brasil pela reforma de 1925, quando foram criados concursos específicos para docentes, entre eles um destinado aos professores leigos, para facilitar a criação de escolas em locais de difícil acesso nas áreas rurais (Vicentini; Lugli, 2009). Depois disso, algumas professoras passaram a ser reconhecidas na profissão, no que se refere ao tempo de serviço e a melhorias salariais, como nos revela Lina:

Depois, com mais ou menos uns quatro ou cinco anos de profissão, veio o concurso público. Eu me lembro como hoje, foi em 95 o concurso pra professor leigo. Eu participei, passei e fui chamada. Depois do concurso eu passei a ser efetiva. O tempo que eu tenho hoje de profissão é contado a partir do concurso.

Naquela época, a aprovação no concurso para professoras leigas era determinante para a identidade profissional das docentes na roça, pois possibilitava a estabilidade e a permanência nas escolas rurais. Porém, o tempo da profissão construído antes do concurso não era validado para as docentes. As quatro docentes perderam nesse processo cerca de cinco a dez anos de atividade, devido à instabilidade no início de suas carreiras. Elas ficaram sem os direitos adquiridos pelo fazer da profissão, sendo esses apenas reconhecidos quando são aprovadas no concurso público.

Outro fator que marcou a oficialização do vínculo da profissão com as prefeituras por meio do concurso público foi a questão salarial. Marta apresenta um pouco desse caminho ao falar das mudanças ocorridas após o concurso para professora leiga:

Quando eu comecei a ensinar, eu não era concursada, mas fiz o concurso no ano seguinte. Como eu era professora leiga, eu fiz para auxiliar de regência. [...] Quando eu comecei ensinar, eu me lembro que minhas colegas recebiam 
$R \$ 200,00$, eu recebia $R \$ 50,00$. Olha que $R \$ 200,00$ não era nem o salário mínimo na época. Eu só recebi um salário mínimo depois do concurso e, mesmo assim, com quarenta horas.

As diferenças salariais apresentadas por Marta ao longo de sua carreira como professora marcam um lugar de precarização e proletarização da profissão docente na roça. Os atrasos e dificuldades no pagamento também foram situações destacadas nos relatos. As docentes leigas sustentaram durante décadas a educação nas áreas rurais, sendo responsáveis pela alfabetização de jovens e adultos na região, porém a valorização e o reconhecimento da profissão não eram evidenciados nos investimentos e, sobretudo, no salário recebido pelas professoras.

Em relação a esse aspecto, só foi possível pensar em um movimento de profissionalização docente na roça após a regularidade do pagamento das docentes, de modo que a profissão pudesse se estabelecer como um trabalho, considerando as condições concretas de sua realização. Um dos caminhos para a busca de melhores condições do trabalho docente na roça deu-se pelo acesso à licença oficial para lecionar, possibilitada pela conclusão do magistério. Em relação à história do professorado primário português, Nóvoa $(1999$, p. 17) apresenta essa licença como uma das etapas de constituição da profissão docente, sendo instituída como um suporte legal para a realização dessa atividade:

A criação desta licença (ou autorização) é um momento decisivo do processo de profissionalização da atividade docente, uma vez que facilita a definição de um perfil de competências técnicas que servirá de base ao recrutamento de professores e o delinear de uma carreira docente. Este documento funciona, também, como uma espécie de "aval" do Estado aos grupos docentes, que adquirem por esta via uma legitimação oficial de sua atividade.

Com a lei n. 5.692, de 1971, a necessidade de Habilitação Específica para o Magistério (HEM) tornou-se uma exigência para a profissão, e as professoras da roça foram convocadas a buscar essa licença oficial para lecionar. No interior da Bahia, a carência de professores habilitados para o exercício do magistério sempre foi um grande problema, principalmente em escolas situadas em áreas rurais. Para sanar parte dessa situação, alguns projetos de formação de professores foram desenvolvidos na rede pública baiana, entre eles o Projeto de Habilitação do Professor Leigo (PROLEIGO). Foi nesse contexto, no início da década de 1990, que as professoras da roça foram convocadas a fazer o curso em seus municípios para a obtenção do diploma do magistério, licença necessária para a continuidade da atuação em sala de aula como docente, entre elas Marta, que nos relata sua experiência:

Com alguns anos depois, surgiu o PROLEIGO, que os professores tinham que fazer para concluir o magistério e continuar ensinando, senão corria o risco de ficar na escola só como merendeira, servente, por não ter a base de conhecimento necessário para ensinar. 
Há, na fala dessa professora, o desejo do diploma, cuja representação vincula-se a um elemento de produção dos saberes necessários à docência, assim como desvela um lugar de transição na busca por referências da profissão na formação docente. O diploma do magistério também possibilitou a Lina falar de outro lugar, na constituição da identidade docente. A identidade de professora é revelada no momento em que há mobilidade, do lugar de leiga para o de professora concursada, revelando-se como um entrelugar na profissão, um lugar de passagem na constituição social da profissão na roça. Lina traz um pouco dessa experiência com o curso de habilitação:

Com o PROLEIGO, nós fizemos até o magistério completo. Nessa época, a gente trabalhava a semana inteira, de segunda a sexta, na sala de aula, um turno porque eu só tenho 20 horas, quando era no sábado, a gente fazia o curso. [...] Foi um curso de aceleração e foi muito bom, porque nós aprendemos muito nesse curso. Sem falar que com o curso a gente ficou autorizada mesmo a lecionar como professora, deixando de ser leiga.

A busca pela formação específica no magistério instigou a docente a outros investimentos pessoais e profissionais, submetendo-a novamente a um processo de formação, feito sob condições precárias. A representação do curso do magistério promovida pelo PROLEIGO - como autorização para lecionar imprimiu qualificações à formação para além das dificuldades enfrentadas, uma vez que a docente buscava a legitimidade da profissão na roça, ameaçada pelas condições de trabalho e pela precária formação adquirida.

Mobilizadas por uma recompensa simbólica e financeira, as docentes da roça esperavam ocupar outro lugar na profissão com a conclusão do magistério. No âmbito dessas expectativas, foram construindo sentidos e significados sobre o estatuto profissional docente, valendo-se de suas próprias trajetórias de formação na profissão e na lida cotidiana da terra.

\section{A PROFISSIONALIZAÇÃO NO EXERCÍCIO DA DOCÊNCIA NA ROÇA}

Para compreender o processo de profissionalização na roça, é necessário levar em consideração, entre outras coisas, as trajetórias formativas das docentes em busca de conhecimentos, normas e princípios específicos da profissão. Ramalho, Núñez e Gauthier (2004) identificam duas dimensões da profissionalização docente, sendo uma interna, chamada de profissionalidade, e outra externa, denominada profissionismo ou profissionalismo. Segundo os autores, a profissionalidade refere-se aos saberes e competências próprias da profissão docente, no contexto da formação inicial e continuada, e das experiências do exercício da profissão, ambos pautados pelos saberes de base do conhecimento do seu campo profissional, da experiência, das disciplinas e dos estudos pedagógicos. $\mathrm{O}$ profissionismo ou profissionalismo relaciona-se às condições, ao contexto do exercício da profissão, à reivindicação de um status distinto dentro da divisão social do trabalho.

Nas escolas da roça, nas quais esta pesquisa foi desenvolvida, a formação das docentes ocorreu, inicialmente, no cotidiano das experiências de lida com a terra, 
com o coletivo, ambiente em que o saber prático foi durante muito tempo o único elemento que fundamentava o agir pedagógico das professoras. Ser da comunidade e ter vivenciado a escola da roça, como estudantes de classes multisseriadas, possibilitou às professoras iniciar o processo de formação docente, exigindo novos paradigmas para a profissionalização.

No final da década de 1990, com a atual LDBEN, exigiu-se a formação em nível superior dos professores das séries iniciais, acarretando, mais uma vez, às professoras da roça a necessidade de outras formações e, consequentemente, a busca pela profissionalização da carreira docente. Nesse período, espalharam-se os cursos de licenciatura pelo interior da Bahia com o PARFOR, chegando mais próximo das docentes da roça. $\mathrm{O}$ advento da licenciatura em pedagogia e a inserção nos cursos de formação continuada, proporcionados pelas secretarias municipais de educação, trouxeram para as professoras algumas das categorias que definem a profissionalidade, como saberes, competências, reflexão, crítica epistemológica e inovação. Elas passaram a ter outras concepções acerca da teoria e da prática desenvolvidas na escola da roça:

Depois que eu concluí o PROLEIGO, eu fiquei um tempo estacionada; quando foi em 2007, a gente começou a fazer o curso de pedagogia pela Rede UNEB/2000. Nós estamos em 2012 e ainda não concluímos. [...] Como demorou muito e tiveram várias mudanças na lei, surgiram mais quatro disciplinas no curso. Nós estamos agora com educação do campo, educação de jovens e adultos e educação inclusiva. Já concluímos educação indígena. [...] Eu participei, ao longo destes anos, também de várias formações; eu fiz o PROFA, que é formação para professores alfabetizadores. Depois eu fiz o FORMA PROCAMPO, que era formação para professores do campo. Eu fiz o CAT, que também foram três a quatro anos de curso. O CAT é conhecer, analisar e transformar para melhorar a vida do homem do campo, através do $\mathrm{MOC} .{ }^{7} \mathrm{E}$ vieram outros cursinhos de formação continuada. A gente nunca parou. (Marta)

Marta traz um itinerário formativo, vivido e experienciado ao longo dos últimos cinco anos de sua carreira. Ela revelou-se uma profissional atenta e disposta a encontrar alternativas para sua prática pedagógica. Os investimentos profissionais voltaram-se para sua qualificação docente, considerando tanto a formação inicial quanto a formação continuada. Percebemos em seu relato a procura pela autonomia docente na construção da profissionalidade, construindo as competências para atuar como profissional da educação do campo. Havia um desejo, inerente ao fazer docente de Marta, por saberes específicos do magistério no meio rural. Identificar-se e reconhecer-se como sujeito da roça, por meio das políticas de educação do campo, fez com que a docente inserisse em seu fazer a sua busca profissional por formações e reinvindicações desse lugar na educação. Estar em formação implicou investimento

$\overline{7 \text { Movimento de }}$ Organização Comunitária. 
pessoal, com vistas à construção de uma identidade profissional específica de uma docente da roça. Segundo Ramalho, Núñez e Gauthier (2004, p. 50):

O processo de profissionalização da docência representa uma mudança de paradigma no que se refere à formação, o que implica sair do "paradigma dominante" baseado na racionalidade técnica, no qual o professor é um técnico executor de tarefas planejadas por especialistas para se procurar "um paradigma emergente", no qual o professor é construtor da sua identidade profissional, segundo os contextos específicos de produção dessa identidade.

Assim, os saberes pedagógicos adquiridos nas formações feitas pelas docentes da roça tornaram-se referências para a ressignificação de sua prática docente em suas comunidades. Nesse contexto, Eva relata que o curso de pedagogia representou a possibilidade de construção de uma nova identidade profissional na escola da roça: "Hoje eu faço o curso de pedagogia na Plataforma Freire e estou no último semestre. Eu me sinto realizada por estar fazendo um curso que me qualifica como professora, não me deixará ser novamente professora leiga". A docente traz da sua memória a alusão a um momento na profissão marcado por elementos de precarização e desautorizações, que não referenciam o lugar do magistério no contexto atual. Sua realização no desenvolvimento do curso está atrelada ao lugar da qualificação da profissão docente, em relação a conhecimentos, experiências e remuneração, que a formação em nível superior deverá produzir em sua carreira.

Ainda na dimensão da profissionalidade, percebemos que os saberes próprios da profissão atravessam e modificam a realidade do meio rural e o próprio trabalho cotidiano das docentes. Isso pode ser visibilizado nas diferentes formas de atuação na profissão e nas escolhas feitas pelas docentes após o processo de formação inicial ao qual foram submetidas, como nos revela Marta:

Depois de tantos cursos, tantas mudanças que ocorreram na educação, não era possível que eu estivesse do mesmo jeito que eu iniciei a profissão. Quando eu comecei, eu trabalhava de uma forma totalmente tradicional, onde meus alunos sentavam um atrás do outro e eram avaliados por prova, único instrumento de avaliação usado. Isso não era só eu que fazia, era o sistema que cobrava. Eu pensava naquela época que os meninos do campo precisavam aprender logo a ler e escrever para sair dali e ir pra cidade arrumar outro jeito de vida, arrumar um emprego. Que o campo não oferecia o que os jovens precisavam para sobreviver, a realidade era essa. A gente tinha essa visão; hoje eu já tenho uma visão totalmente diferente. Hoje eu acho que a gente deve estudar e se profissionalizar para a gente sobreviver no campo. Só que a gente tem que buscar muita coisa que o campo não tem, como essa questão da tecnologia. Nossos alunos do campo hoje precisam estar o tempo todo ligado com a tecnologia, porque a zona rural de hoje não é aquela que a gente tinha há muito tempo atrás.

A professora mostra que, além dos conhecimentos sistematizados, outros entendimentos complementam o processo da profissionalidade, provenientes da 
comunidade a que a professora pertence. O sentimento de pertencimento ao grupo e os saberes proporcionados pela formação inicial e continuada produzem outro olhar sobre a realidade dos sujeitos do campo. Tais saberes e conhecimentos orientam a ação profissional e educativa da docente, pois a compreensão da professora sobre a profissão também é influenciada pelo vivido. Nesse movimento de compreender o processo de instrução docente, Marta caminha da formação para a autoformação, apresentando-as como processos que se intercomunicam na constituição da profissão docente na roça. Conforme Arantes (2009, p. 33):

[...] considerar a vivência significa imergir e buscar identificar, conhecer e compreender o significado e o sentido dos acontecimentos escolares. Pressupõe conhecer as pessoas envolvidas e também o significado e o sentido que elas dão aos acontecimentos vivenciados.

O curso superior aparece nas trajetórias de formação das docentes pela necessidade do aprofundamento dos conhecimentos específicos da atividade, mas, além disso, surge pela busca do reconhecimento social da profissão, expresso na melhoria salarial, nas condições de trabalho e no exercício efetivo da carreira docente. Nesse sentido, o profissionalismo é tomado como uma postura política das professoras da roça. Elas narram a procura pela autonomia docente, perdida ao longo dos anos por conta da precarização do ensino nas escolas rurais:

Professor é uma profissão árdua, é uma responsabilidade muito grande. [...] Eu sei que é uma responsabilidade muito grande e tem momento que é muito angustiante, quando a gente passa por decepções. Eu, por várias vezes, passei por questão de gestores que não valorizaram o professor. Tem vez que até alguns pais não valorizam ou não valorizavam o trabalho do professor, mas tem também aqueles que valorizam e deixam a gente orgulhosa. [...] Eu acredito que em toda profissão tem isso, mas a profissão de professor é mais questionada. Hoje, com o conhecimento que eu tenho, eu acho que é uma responsabilidade muito grande que a gente tem nas mãos. $\mathrm{Na}$ época que eu comecei a ensinar, eu não me preocupava assim tanto, eu estava ensinando ali a ler e escrever. Era isso que a gente pensava, porque foi assim que a gente aprendeu. (Eva)

Nesse fragmento da narrativa de vida-formação-profissão, Eva refere-se ao lugar ocupado pelo professor nas relações sociais em que a docência está inserida, ressaltando que o reconhecimento da atividade do professor é fundamental para o desenvolvimento da profissão, considerando o nível de responsabilidade que exige, que não se limita ao ensino das primeiras letras.

Ao narrar esse momento de sua vida, em um movimento de formação, a docente reflete sobre o lugar que ocupa hoje nas escolas da roça, após ter acessado outros saberes, outras competências. Nesse sentido, pensar na docência na roça como profissão implica reconhecê-la como produtora de identidade profissional construída em um contexto voltado para a semiótica da terra, em que os sujeitos são mobilizados por um fazer não apenas ideológico, mas social, político e econô- 
mico, por saberes próprios do meio rural em que estão inseridos. A dimensão do profissionalismo presente no relato da professora apresenta-se com base em uma necessidade de reconhecimento da docência na roça, necessidade que é expressa na problemática da construção da profissão.

$\mathrm{Na}$ procura pela legitimação desse magistério, algumas professoras organizaram-se por meio do Sindicato dos Trabalhadores em Educação do Estado da Bahia (APLB-Sindicato), criado em 1989 pelas iniciativas regionais para mobilizar a categoria docente por melhorias na profissão. Nos anos de 1990, na maioria dos municípios do interior da Bahia, iniciava-se a organização do movimento sindical docente. Nesse período, o sindicato dos professores municipais da região pesquisada, Piemonte da Diamantina, viveu muitas dificuldades políticas e financeiras, além dos enfrentamentos com o autoritarismo dos políticos locais, resultando muitas vezes em perseguições. Essas dificuldades ampliaram-se por conta da municipalização do ensino e do aumento do número de docentes em seu quadro efetivo, pois tornavam ainda mais complexas as relações existentes nesse sistema de ensino.

A relação profissão/sindicato foi sendo construída nas histórias de vida das docentes da roça com base na dimensão coletiva da profissionalização, considerando as dificuldades enfrentadas pelas professoras na realização do trabalho nas escolas. É nesse movimento de tensão vivido pelas docentes ao longo da profissão que surge o desejo de lutar pela carreira. A busca de novos salários, de organização coletiva por meio dos sindicatos, a procura pelo reconhecimento e o prestígio social da categoria envolveram todas as professoras colaboradoras desta pesquisa. Eva mostra esse momento na sua narrativa de vida-formação-profissão descrevendo o lugar do sindicato em relação às mudanças no plano de carreira dos docentes de seu município, impactando na melhoria salarial:

$\mathrm{Na}$ minha carreira, já participei de muitas manifestações e organizações de professores. Teve uma época que surgiu o sindicato aqui eu era quase a líder, porque eu era daquelas que dizia mesmo a verdade, discutia, enfrentava prefeito, enfrentava secretária de educação. Nesse período, a gente conseguiu avanços, como a questão salarial que melhorou bastante, ficando com o piso nacional. Teve uma época, também, que aqui era um dos municípios que estava com o salário de professor melhorzinho na região, por conta da nossa luta. Nós mexemos com o plano de carreira, que foi feito em 2010, sancionado pelo prefeito, mas agora vai ter outra mudança, por conta da formação dos professores.

No campo da formação, os docentes vivem a realidade política pela construção coletiva que deu sentido orgânico à profissão na roça. Eva apresenta essa situação ao mostrar os enfrentamentos que os professores tiveram de encarar para a institucionalização dos direitos da categoria, mediante o plano de carreira. Nesse caso específico da docência na roça, a profissionalização é construída paralelamente a uma autonomia crescente perante as dificuldades de consolidar uma carreira profissional historicamente negada aos sujeitos do meio rural em condições materiais, sociais e políticas. 
Na luta travada pelo movimento docente na região, os professores da rede municipal reivindicavam a valorização da profissão, incluindo melhores salários, planos de cargos e carreira para o desenvolvimento do magistério. Essas questões faziam parte da realidade das professoras, mobilizando a luta pela profissão na roça. A formação comunitária e a atividade nos sindicatos rurais foram momentos de aprendizagem inicial dessas docentes na participação e construção ativa da profissão, por meio de sua atuação nas associações.

Houve uma manifestação, uma certa época, que foi para sancionar o estatuto. Vários professores participaram. O estatuto foi sancionado e agora a discussão é que o município não tem condição de pagar o que rege no estatuto. Isso já tem uns quatro anos e agora está em discussão, porque o salário não pode baixar e o gestor alega que os recursos da prefeitura não dão para pagar o salário para professores graduados e pós-graduados. Por conta disso, ele não mudou o nível dos professores, só mudou até agora os professores da primeira turma que graduou e pós-graduou. Agora, está uma discussão porque não tem recursos para manter o que foi assegurado para os professores. Eu não sei o que vai acontecer, mas a gente vai lutar novamente, porque nós conseguimos isso com a luta do sindicato e temos que garantir. (Eva)

A profissionalização docente na roça foi atravessada pela formação do profissional, pelas condições materiais de trabalho e pela busca de autonomia. Eva apresenta as diferentes fases da "desprofissionalização" que as professoras vivenciaram perante as demandas por novas condições de trabalho e novos salários, condições que foram mobilizadas pelos investimentos feitos ao longo da carreira de docente na roça. As professoras precisaram reivindicar o lugar da profissão no chão da terra em que foram nascidas, criadas e formadas, baseadas em demandas desse contexto específico, para que pudessem legitimar os saberes produzidos nesses lugares. Assim, a profissionalização na roça se fez como um movimento contínuo na vida dessas professoras, que vivem a profissão na relação direta com a diversidade presente nas práticas sociais, políticas e formativas do campo.

\section{CONSIDERAÇÕES FINAIS}

Nas narrativas de vida-formação-profissão, as docentes da roça apresentaram o projeto de si, no qual a história profissional de cada uma esteve interligada à vida pessoal. Conhecer as condições que caracterizam o exercício da docência na roça, bem como os percursos dessas professoras, foi fundamental para se compreender a história da profissão docente no Brasil, pois não se trata de:

[...] uma história contínua, de progressiva e crescente profissionalização: há momentos de perda de autonomia, há momento de perda de controle sobre algum elemento do campo, que corresponderia, grosso modo, à desprofissionalização. Para além disso, como se trata de um grupo social tão diverso em seu interior e submetido a condições tão distintas por todo o país, o que se pode 
dizer é que essa história contém ao mesmo tempo processos profissionais e não profissionais, dependendo do lugar e do grupo para o qual se atente, ou seja, no mesmo período parte dos docentes pode estar mais profissionalizada do que outros. (Vicentini; Lugli, 2009, p. 24)

A pesquisa revelou que a atuação das docentes leigas foi de extrema importância para a inserção da profissão no espaço rural, considerando os vínculos que tinham com as comunidades e os reflexos da presença da escolarização nesses lugares. Iniciar a carreira em escolas isoladas, sendo essas, muitas vezes, suas próprias casas, a falta de recursos, a baixa remuneração, tudo isso marcando a entrada desses profissionais na educação na roça. Da lavoura à docência: esse foi um percurso feito por todas, sendo que algumas se tornaram professoras lavradoras, dividindo o tempo com a agricultura familiar, com o marido, pais e irmãos.

O que podemos perceber ao longo das narrativas é que as professoras produziram a profissão em meio à escola da roça, que essa foi construída por elas, a partir dos itinerários de formação. Para compreender o processo de constituição da profissão docente na roça, é imprescindível levar em consideração as condições concretas em que o trabalho foi construído, incluídas aí as condições precárias em que as atividades docentes foram exercidas e as condições institucionais a que a profissão foi submetida. Esse processo foi marcado, na trajetória das docentes, por descontinuidades, retrocessos e avanços, compondo a profissão docente na roça.

$\mathrm{Na}$ busca pela profissionalização, as professoras foram ao encontro da formalização dos saberes específicos da docência, reivindicando o status de professor da roça e visando à construção de uma autonomia centrada na contextualização dos conhecimentos produzidos na realidade do meio rural. Essas ações deram contornos a uma nova profissionalidade docente, com base em uma dimensão tripla, que envolveu o pedagógico, o institucional e o político. Nesse sentido, os professores reconfiguraram os modos de aprender e ensinar na roça, voltando-se também para o reconhecimento social da carreira por meio do profissionismo. Esse processo foi marcando as diferentes faces e fases da profissionalização tão almejada pelas docentes da roça, encontrando-se ainda num movimento contínuo de busca pela legitimação dessa profissão.

A docência nas escolas do campo precisa ser pensada como um compromisso ético e político dos gestores, para que assim possam formar de fato profissionais voltados para a realidade das comunidades rurais. Diante disso, a gestão pública exerce um papel fundamental no reconhecimento da profissão e na implementação de políticas que garantam novas formas de profissionalização para os docentes da roça. Essas ações são fundantes para que possamos pensar a educação no meio rural, com base em outras lógicas que contrariem o que foi definido como o modelo tradicional da escolinha rural, e avançar na construção de uma nova legitimidade da profissão docente nesse contexto. 


\section{REFERÊNCIAS}

Arantes, V. A. Profissão docente: pontos e contrapontos. São Paulo: Sumus, 2009.

Aтta, D. Escola de classe multisseriada: reflexões a partir de relatório de pesquisa. In: Programa de Apoio ao Desenvolvimento da Educação Municipal- PRADEM. Escola de classe multisseriada. Salvador: Universidade Federal da Bahia; Fundação Clementino Mariani, 2003. (Série Grupos de Estudo, 1,28p.)

Bahia. Decreto n. 12.354, de 25 de agosto de 2010. Institui o Programa Territórios de Identidade e dá outras providências. Governo do Estado da Bahia, 2010.

Lei n. 1.846, de 14 de agosto de 1925. Reforma a Instrucção Publica do Estado da Bahia. Palacio do Governo do Estado da Bahia, 1925.

Benjamin, W. Magia e técnica, arte e política: ensaios sobre literatura e história da cultura. São Paulo: Brasiliense, 1994.

Brasil. Lei n. 5.692, de 11 de agosto de 1971. Fixa Diretrizes e Bases para o ensino de $1^{\circ}$ e $2^{\circ}$ graus, e dá outras providências. Diário Oficial da União, Brasília, DF, 12 ago. 1971. Seção 1, p. 6.377.

. Lei n. 9.394, de 20 de dezembro de 1996. Estabelece as Diretrizes e Bases da Educação Nacional. Diário Oficial da União, Brasília, DF, 23 dez. 1996. Seção 1, p. 27.833-27.841.

. Ministério da Educação. Resolução CNE/CEB n. 1/2002. Diretrizes Operacionais para a Educação Básica nas Escolas do Campo. Brasília, DF: CNE/CEB. 2002.

Decreto n. 6.755, de 29 de janeiro de 2009. Institui a Política Nacional de Formação de Profissionais do Magistério da Educação Básica, disciplina a atuação da Coordenação de Aperfeiçoamento de Pessoal de Nível Superior - CAPES no fomento a programas de formação inicial e continuada, e dá outras providências. Diário Oficial da União, Brasília, DF, 30 jan. 2009a.

. Portaria n. 9, de 30 de junho de 2009. Institui o Plano Nacional de Formação dos Professores da Educação Básica no âmbito do Ministério da Educação. Diário Oficial da União, Brasília, DF, 1 jul. 2009. Seção 1, p. 9, $2009 \mathrm{~b}$.

Inep - Instituto Nacional de Estudos e Pesquisas Educacionais Anísio Teixeira. Censo escolar 2010. Sinopse estatística da educação básica - Ano 2010. Brasília: MEC; INEP, 2010. Disponível em: <http://www.inep.gov.br/basica/censo/>. Acesso em: 20 abr. 2013.

Panorama da educação do campo. Brasília: MEC; INEP, 2007.

Josso, M. C. Experiências de vida e formação. Trad. de José Cláudino e Júlia Ferreira. São Paulo: Cortez, 2004.

NóvoA, A. Para o estudo sócio-histórico da gênese e desenvolvimento da profissão docente. Teoria E Educação, Porto Alegre: Parannoica, n. 4, p. 109-139, 1991.

(Org.). Profissão professor. Porto, Portugal: Porto Editora, 1999.

Picanço, I. S. Alguns elementos para discussão sobre o professor leigo no ensino brasileiro. Em Aberto, Brasilia: INEP, ano 5, n. 31, p. 9-12, out./dez. 1986. 
Ramalho, B. L.; Núñez, I. B.; Gauthier, C. Formar o professor, profissionalizar o ensino: perspectivas e desafios. 2. ed. Porto Alegre: Sulina, 2004.

Rıos, J. A. V. P. Ser e não ser da roça, eis a questão: identidades e discursos na escola. Salvador: EDUFBA, 2011.

Vicentini, P. P.; Lugli, R. G. História da profissão docente no Brasil: representações em disputa. São Paulo: Cortez, 2009.

\section{SOBRE A AUTORA}

Jane Adriana Vasconcelos Pacheco Rios é doutora em educação pela Universidade Federal da Bahia (UFBA). Professora titular da Universidade do Estado da Bahia (UNEB).

E-mail: jhanrios1@yahoo.com.br

Recebido em fevereiro de 2014 Aprovado em junbo de 2015 